\title{
Positive Politeness Strategies Used by the Character in the Movie The Patriot
}

\author{
Ni Luh Hani Rainna Wati*, Ida Ayu Made Puspani \\ English Department, Faculty of Arts, Udayana University \\ [raina.hany@gmail.com] \\ Denpasar, Bali, Indonesia \\ *Corresponding Author
}

\begin{abstract}
Abstrak
Tujuan dari penelitian ini adalah untuk menemukan jenis strategi kesopanan positif yang diucapkan oleh para tokoh dalam film The Patriot dan pengaruh jenis kelamin pada tingkat kesopanan tokoh tersebut dalam film The Patriot. Sumber data dari penelitian ini berasal dari film The Patriot yang kemudian diklasifikasikan berdasarkan jenis kesopanannya dan jenis kelamin tokohnya. Selanjutnya, data yang telah diklasifikasikan dianalisis secara kualitatif menggunakan teori Kesopanan yang dicetuskan oleh Brown dan Levinson (1978), dan teori Sosiolonguistik yang dicetuskan oleh Ronald Wardhaugh (2010). Hasil dari penelitian ini menunjukkan bahwa tokoh-tokoh dala, film The Patriot menggunakan sebelas dari limabelas strategi kesopanan positif dan wanita cenderung secara konsisten menggunakan tingkat kesopanan netral dalam berbicara, sedangkan pria lebih menggunakan tingkat kesopanan yang bervariasi, dalam berbicara dengan lawan bicaranya.
\end{abstract}

Kata kunci: Kesopanan, jenis kelamin, tingkat kesopanan

\begin{abstract}
The aims of this study is to figure out the used of politeness strategy uttered by the character in The Patriot movie and the influence of gender to the level of politeness within the movie. Documentation method and note-taking technique were applied in collecting the data of this study. The data were obtained from the movie The Patriot, furthermore, the data were classified based on their types of politeness and also based on the speaker's gender and analysed qualitatively using the theory of Politeness proposed by Brown and Levinson (1978) and the theory of sociolinguistics proposed by Ronald Wardhaugh (2010). The analysis revealed that the character in the movie The Patriot applied eleven out of fifteen strategies proposed by Brown and Levinson. Regarding to the gender of the character, women consistently tend to use neutral style when they have conversations both with women or men. On the other hand, men are using various levels of formality when they have conversation.
\end{abstract}

Keywords: Politeness, gender, level of formality

\section{INTRODUCTION}

Many people think that politeness is as simple as bowing in front of people in order to show a respect, to greet someone else, or even only saying excuse me, sorry, please, or thank you. However, politeness is sometimes a complicated thing. What considers as polite in a country, perhaps it is impolite in another country. Naoto and William (2000) argue 
that politeness in a country is more affected by the culture, for instance politeness in Japan is different than politeness in the US.

The purpose of politeness itself is to make all of the parties relaxed and comfortable with one another. Besides it also take an important role in a peace mission, politeness can avoid a conflict. Apologizing, which is a classic form of politeness, is an obvious conflict avoider as would be such expressions as you are right, please forgive $m e$, and I was wrong, it can help create a more positive atmosphere which is likely to help minimize the feelings of conflict and opposition.

According to Brown and Levinson (1987), there are four main types of politeness strategies: bald on-record, negative politeness, positive politeness, and off-record. This study focuses on finding the positive politeness strategy used by the character in The Patriot movie.

Gender is one of many factors that make people apply the different type of politeness. Many researchers believe that men and women speak differently. It can be different in terms of the vocabulary choices, syntax, pronunciations, and even the intonation as Xiufang Xia (2013) remarks. Society is also playing a crucial role in making it difference. Nemati (2007) claims that although men and women, from a given social class, belong to the same speech community, they may use different linguistic forms. The linguistic forms used by women and men contrast to some extent in all speech communities. It can be simplified that men learn to talk like men and women learn to talk like women.

There are two problems which can be formulated based on the background that explained above, that are:

a. What politeness strategies are used by the characters in The Patriot movie? b. How does the gender of the speaker influence the level of politeness in The Patriot movie?

Based on the problems mentioned above, this study aims at answering the problems which are described as follows:

a. To figure out the use of politeness strategy uttered by the character in The Patriot movie.

b. To analyse the influence of gender to the level of politeness within the movie.

\section{METHOD}

This part focuses on describing the data source (where the data were taken from), method and technique of collecting the data (how the data were collected), method and technique of analysing the data (how the data were analysed), as well as method and technique of presenting the data (how the data are presented).

\section{Data source}

The data of this study was taken from a movie entitled The Patriot. That movie was chosen due to it was interesting and contained many politeness strategy which was related to the topic of this study. The Patriot is an American historical war film which tells about Revolutionary War of America directed by Roland Emmerich, written by Robert Rodat, and starring by $\mathrm{Mel}$ Gibson, Chris Cooper, Heath Ledger, and Jason Isaacs. The film mainly takes place in South Carolina.

\section{Method and Technique of Collecting Data}

This research applied library research as well as documentation methods in collecting the data. Whereas the techniques were watching the whole movie, note-taking, and classify the data based on the politeness of the speakers and the level of its politeness. 
The first step was watching and making the transcription of the movie carefully in order to obtain the data accurately. After watching and transcribing the movie, the next step was taking notes on important points found within the movie. The last step but not least was classifying and analysing the data based on their type and level of the politeness.

\section{Method and Technique of Analysing Data}

The data of this study was analyzed using descriptive qualitative method. Qualitative research is a type of social science research that collects and works with non-numerical data and that seeks to interpret meaning from these data that help us understand social life through the study of targeted populations or places. First, the politeness strategy within The Patriot movie was analyzed by using theory of politeness strategy proposed by Brown and Levinson (1978). Second, the influence of gender on the level of politeness was analyzed by using theory of sociolinguistics proposed by Ronald Wardhaugh (2010).

\section{Method and Technique of Presenting the Analysis}

In this study, the used of politeness strategy in The Patriot movie was presented in informal method. The analysis was descriptively explained by using words to give a clear explanation.

\section{FINDINGS AND DISCUSSIONS}

\section{Types of Positive Politeness Strategies found in The Patriot Movie.}

a) Strategy 1 - Notice, attend to $H$ (his interests, wants, needs, goods)

Nathan: Father, a post rider! Benjamin: Did you finish planting the field? (Source:

http://www.veryabc.cn/movie

/uploads/script/ThePatriot.txt)

Analysis:

In the part of the conversation above, Benjamin tries to take notice of Nathan's condition by asking him about his duty whether he has finished it or not because he knows that his son is very excited to read the mail, in this case, Benjamin's utterance shows the manner of maintaining and satisfying Nathan's wants or interests. Moreover, Nathan would feel comfortable and calm because he knows that his father will be waiting for him to read the mail, therefore, he can finish his duty without worrying about the mail.

b) Strategy 3 - Intensify interest to $\mathrm{H}$

Gabriel: $\quad$ Miss Howard, isn't it?

Miss Howard: You know who I am, Gabriel Martin. The last time you saw me, I was 11 and you put ink in my tea.(Source: http://www.veryabc.cn/ movie/uploads/script/T hePatriot.txt)

Analysis:

In this part of the conversation shows that Gabriel wants to intensify his interest to the hearer, in here is Miss Howard. The conversation above happen when Benjamin indirectly meet Miss Howard right after the congress was held in Charles Town. Actually he only wants to make sure that she is Miss Howard because he does not meet her for a long time.

The statement "Miss Howard, isn't $i t$ ?" is using a tag questions which is "isn't it". In this case, the use of tag question is one of the feature of this politeness strategy propose to draw $\mathrm{H}$ as a participant into the conversation. 
c) Strategy 4 - Use in-group identity markers

Benjamin: It's a good spot! Boys, listen to me. I'll fire first. I want you to start with the officers and work your way down. Can you tell the difference?

Nathan: Yes, Father!

Samuel: Yes, Father!

Benjamin: Good. Samuel, after your first shot, reload for Nathan. Now, if anything should happen to me, I want you to drop your weapons. And run as quickly as you can. Get your brother and your sisters and take them to Aunt Charlotte's. Understood? What did I say about shooting?

Samuel and Nathan: Aim small, miss small. (Source: http://www.veryabc.cn/movie/ Analysis: uploads/script/ThePatriot.txt)

The statement "Aim small, miss small" stated by Benjamin's children, Nathan and Samuel is using the fourth strategy of positive politeness, namely use in group identity marker. This part of conversation happen when Thomas is brutally shot by British Colonel, when he tries to save his brother from a hanging punishment. Seeing this situation, Benjamin ask Nathan and Samuel to do a revenge by killing some of the British soldier and save his older son. Benjamin tells his son to aim small, miss small before they shoot.

The utterance "aim small, miss small" in this case is using the strategy of contraction and ellipsis. It is due to both $\mathrm{S}$ and $\mathrm{H}$ is shared the same knowledge to make this ellipsis apprehensible. It can be simplify that Benjamin and his Children have the mutual intelligence about shooting because in the past Benjamin is a soldier and he taught his children how to shoot. d) Strategy 5 - Seek agreement

Benjamin: Well, the assembly's been convened, so I've been called to Charles Town.

Thomas: Charles Town? We're going to Charles Town?

Benjamin: We are. We leave in the morning. (Source: http://www.veryabc.cn/movie/ uploads/script/ThePatriot.txt)

Analysis:

On the part of the dialogue above, seek agreement strategy is applied by Benjamin's son, Thomas. In here, Thomas applied one of the seek agreement strategy which is repetition. In this case, Benjamin states that he will go to Charles Town because the assembly has been convened, and Thomas, repeating the word "Charles Town" that has been said by Benjamin.

The use of repetition here is to make sure that Thomas has heard what is Benjamin said correctly. Besides, repeating is also used to stress emotional agreement with the utterance.

e) Strategy 6 - Avoid disagreement

General O'Hara: Finished, My Lord. I've taken it in at the back, added wider epaulets and looped gold braiding.

General Cornwallis:It's a horse blanket

Colonel Tavington:I don't know, My Lord. It's really quite nice.

General O'Hara: Very nice, My Lord.

General Cornwallis: Very well. It's a nice horse blanket.

(Source:

http://www.veryabc.c n/movie/uploads/scrip

Analysis: $\mathrm{t} /$ ThePatriot.txt)

The part of dialogue above is applied one of the positive politeness strategy proposed by Brown and Levinson which is avoid disagreement, specifically using 
strategy of white lies. The conversation above is talking about General Cornwallis's coat and he seems not really love to wear it. It can be seen on his statement "It's a horse blanket.", however, Colonel Tavington and General O'Hara try to maintain General Cornwallis's positive face by saying "I $t$ ' $s$ really quite nice."

In this case, both $\mathrm{S}$ and $\mathrm{H}$ know that the coat is not suit with General Cornwallis, however $\mathrm{H}$ does not want to make $\mathrm{S}$ lose his positive face by saying something bad about it moreover the speaker has a higher position than the hearer. That is why, $\mathrm{H}$ in this case applies white lies strategy to avoid disagreement and maintain $\mathrm{S}$ positive face.

f) Strategy 8 - Joke

Reverend Oliver: It's the personal correspondence of Lord Cornwallis. It is his journal!

John Billings: I say we drink the wine, eat the dogs and use the papers for musket wading.

Reverend Oliver: Eat the dog?

Benjamin: Dog is a fine meal!

Reverend Oliver: G-G-God heavens!

(Source:

http://www.veryabc.cn/movie/uploads/sc ript/ThePatriot.txt)

Analysis:

The utterance uttered by John Billings above is applied the eighth strategy of positive politeness namely, joke. It is one of the basic strategy of positive politeness strategy. Besides, joke only can be done by two person or more who have the same background of knowledge and values. On the part of the conversation above, it shows that Benjamin and John Billings have the same background of knowledge.
However, Reverend Oliver is not. It is proved by when John Billings says "I say we drink the wine, eat the dogs and use the papers for musket wading." Benjamin response is "Dog is a fine meal!". In this case, joking is use to put $\mathrm{H}$ 'at ease'. Benjamin's response shows that he wants to save John Billing's positive face so that he can maintain the solidarity between them.

g) Strategy 9 - Assert or presuppose S's knowledge of and concerns for H's wants

Benjamin: I know your men have sacrificed a lot so far. But all I'm asking is that you let the front line of the militia fire two shots tomorrow.

Colonel Burwell: A lot can happen in the time it takes.

Benjamin: $\quad$ Indeed. That's why I'm not asking to fire three.

(Source:

http://www.veryabc.cn/ movie/uploads/script/T hePatriot.txt)

Analysis:

The part of the conversation above is talking about war strategy. In here, Benjamin wants his militia to fire twice by saying 'I know your men have sacrificed a lot so far. But all I'm asking is that you let the front line of the militia fire two shots tomorrow.' This statement is applied the ninth strategy, which is assert or presuppose S's knowledge of and concern for H's wants.

Benjamin wants Colonel Burwell allows his militia to fire twice tomorrow when the war begin. It means that Benjamin and Colonel Burwell have cooperated for same goals, and also Benjamin conveys his wants to ensure that his militia will fire twice. It indicates that he as the speaker has a potentials to 
put pressure on Colonel Burwell to cooperate with him. Furthermore, Benjamin asserts or presupposes of Colonel Burwell's wants and willingness directly. It is because they have known each other and has a close relationship, because they have become partners in this war. In this case, Benjamin has fulfilled Colonel Burwell's positive face by conveying his wants to ensure that America will be the winner in this war. As a matter of fact Colonel Burwell also wants to make American troops win the war so that America became an independent country.

h) Strategy 10 - Offer, promise

Colonel Burwell: He's as imprudent as his father was at his age.

Benjamin: Regrettably so.

Colonel Burwell: I'll make sure that he serves under me. Make him a clerk or quartermaster, something of that sort.

Benjamin: $\quad$ Good luck! (Source: http://www.veryabc.cn/movie/uploads/sc ript/ThePatriot.txt)

Analysis:

The part of the conversation above shows the use of the tenth strategy of positive politeness which is offer, promise. In this case, Colonel Burwell promises Benjamin to take care of his son by saying "I'll make sure that he serves under me. Make him a clerk or quartermaster, or something of that sort." This conversation happen when Gabriel join the troops against British without his father's permission. Knowing that Benjamin is unhappy with his son's decision, Colonel Burwell as the Colonel try to calm Benjamin down by promising him that his son would be safe and sound under his command.

Promising something is one of the positive politeness strategy, in this case is used to show S's cooperation towards $\mathrm{H}$. Besides, Colonel Burwell is also wants to show his intentions in satisfying Benjamin's positive-face wants.

i) Strategy 12 - Include both $\mathrm{S}$ and $\mathrm{H}$ in the activity

Benjamin: Six-pounders. Lots of them. Nathan: How far away?

Benjamin: They're a long way off.

They're most likely heading the other direction. Put those in the house!

Thomas: Father! They might come this way!

Benjamin: Thomas! Must I tell you again? Let's all stay close in to the house tonight, all right? (Source: http://www.veryabc.cn/movie/ uploads/script/ThePatriot.txt)

Analysis:

The statement "Let's all stay close in to the house tonight, all right?" which is said by Benjamin is using one of the positive politeness strategy which is include both $\mathrm{S}$ and $\mathrm{H}$ in the activity. In here, he uses the word 'Let' $s$ ' and 'all' in his statements to stressed the cooperativeness of S's action and to show what he really means by all which is 'you' and 'me'. In this case, Benjamin as a father wants all of his children including himself to come into the house because he does not want his children see the shooting between British and American soldier. Moreover, the use of this strategy in this case also can make the request more polite, it is because the use of inclusive 'we' indicate that both $\mathrm{S}$ and $\mathrm{H}$ want the same goals which is in this case is to stay safe in the house.

j) Strategy 13 - Give (or ask for) reasons General Cornwallis: O'Hara, our supply ship appears to have arrived. 
General O'Hara: $\quad$ Yes, My Lord. It has.

General Cornwallis: Then, why am I still wearing this rag?

General O'Hara: $\quad$ My Lord, your replacement wardrobe is aboard ship. But, Colonel Tavington thought it best to secure our arms and munitions first. They are being unloaded. (Source: http://www.veryabc. $\mathrm{cn} /$ movie/uploads/sc ript/ThePatriot.txt)

Analysis:

The statement stated by General Cornwallis above which is "then, why am I still wearing this rag?" is applied one of the positive politeness strategy which is the strategy of give or ask for reason. In here, General Cornwallis asked General O'Hara why he is still wearing a low quality cloth that looks like a rag while his supply ship has arrived, indicated by the use of "why" in his first sentence. In this case, General Cornwallis tries to include General O'Hara in an activity by asking the reason why he still uses it. Furthermore, General Cornwallis uses this strategy in order to complaint to General O'Hara or in other word General Cornwallis expect a cooperation from General O'Hara by asking him a reason, because giving reason is a way of implying 'you can help me'.

k) Strategy 15 - Give gifts to H (goods, sympathy, understanding, cooperation)

\section{Gabriel: $\quad$ Father, I am sorry about} Thomas.

Benjamin: Oh Son, that wasn't your fault. That was mine.

(Source:

http://www.veryabc.cn/movie /uploads/script/ThePatriot.txt)
Analysis:

The statement stated by Gabriel above "Father, I am sorry about Thomas." applies the last strategy of positive politeness which is give gifts to $\mathrm{H}$ (goods, sympathy, understanding, cooperation). This part of the conversation happens when Gabriel being stabbed by Colonel Tavington and he remember of his brother Thomas, who is brutally killed by Colonel Tavington too after trying to save Gabriel from the hang punishment. Because of it, he feels guilty and says sorry for the last time to his father. In this case, Gabriel tries to fulfil Benjamin's want by redress Benjamin's face directly by fulfilling some of his wants, thereby it indicates that Gabriel wants Benjamin's wants.

In here, $S$ tries to satisfy H's positive-face want by actually satisfying some of H's wants. Furthermore, gifts in this strategy is not solely means a physical gifts. It also can be a want the wants to be liked, admired, cared about, understood, and listened to.

Analysis of the Influence of the Character's Gender to the Level of Politeness within The Patriot Movie.

a) Conversations between man and woman

Data 1 [02:01:12 - 02:01:43]

Anne: I'm sorry we didn't give you more warning.

Benjamin: It's fine. I have something for you. It belonged to Gabriel's mother.

Anne: It's beautiful.

Benjamin: Allow me? It's the North Star. That's the only star in the sky that never moves. It's constant, unwavering. A guide.

Anne: I'd be honoured (Source: http://www.veryabc.cn/movie/uploads/sc ript/ThePatriot.txt) 
Analysis:

The part of conversations above is talk about Anne's apologizing because she does not tell Benjamin more about her wedding. The statement stated by Anne which is 'I'm sorry we didn't give you more warning" is shows that she tries to be involved with the hearer, indicating by the use of word ' $w e$ ' in her sentence. In this case, Anne uses the word 'we' not solely try to involve with the hearer, but she use it to create and maintain social cohesiveness with Benjamin as her father-in-law and their activities are generally co-operative and non-competitive. While Benjamin's response 'It's fine. I have something for you. It belonged to Gabriel's mother.' is shows his dominance. He is more likely to ignore what has been said before and stress his point of view. As Benjamin's daughter-in-law, Anne applies the neutral style when talking to Benjamin. It is due to, Anne is now belong to Benjamin's family after got married to Gabriel.

Data 2 [00:09:37 - 00:09:58]

Children: Aunt Charlotte!

Charlotte: Margaret, William, look at you. Missed you. They're huge. What have you been feeding them?

Benjamin: Well, they're from good stock. On their mother's side, of course.

Charlotte: Thank you. Come inside. Wait until you see what I have.

Children: Present? Present for us?

(Source:

http://www.veryabc.cn/movie/uploads/sc ript/ThePatriot.txt)

Analysis:

The scene shows that Benjamin and his children come to Charles Town to attend the Continental Congress and also visit their aunty, Charlotte. Charlotte is so excited to welcome her nephew and niece because she has not seen them for a long time since her sister passed away. She is shock seeing Benjamin's children because they have grown up very fast and healthy. It is reflected in her first utterance 'Margaret, William, look at you. Missed you. They're huge. What have you been feeding them?' and Benjamin respond to it by saying that his children are from a good stock from their mother side. In here, Benjamin tries to involve his sister-in-law in an activity by showing her indirect contributions into it.

The utterance "Thank you" which is stated by Charlotte applies a neutral level of politeness and can be categorized as the women's language feature as a super polite form. It is kind of super polite form as a polite answer. It shows that Charlotte reflect polite answer which does not need the listener to reply to her statement. From the utterance above, it indicates that Charlotte shows polite behavior as Benjamin's sister-in-law. She thanks politely as the respond towards Benjamin's praise. She wants to convey her feeling that she is being grateful for everything that Benjamin has done for her by using the super polite form.

b) Conversations between man and man

Data 1 [01:37:45 - 01:38:10]

Benjamin: I'm a colonel in the Continental Army. My rank should be sufficient for now.

General Cornwallis: As you wish. Please be seated.

General Cornwallis: Would you, as the initiating officer, care to begin?

Benjamin: I will, unless you'd like to claim aggrieved status.

General Cornwallis:Yes! I would like to claim aggrieved status. 
Benjamin:

\author{
Very well, Sir. \\ Proceed. (Source: \\ http://www.veryabc.c \\ n/movie/uploads/scrip \\ $\mathrm{t} /$ ThePatriot.txt)
}

Analysis:

The statement stated by General Cornwallis above "would you, as the initiating officer, care to begin?" is applies the formal style of politeness level, besides, the utterance is also indicating that man is using language to make things done. It means that language behaviour reflects male dominance. In this case, General Cornwallis as British General use his power to dominate and constantly try to take control of Benjamin who come to British office with white flag in order to set his militiamen free. It can be seen from General Cornwallis's statement, he use the word 'you' when he asks Benjamin to begin the discussion about prisoner exchange. The word 'you' in this case is also indicating that $\mathrm{S}$ ask $\mathrm{H}$ to begin the discussion directly, as a matter a fact, the more direct a statement means the more impolite it is.

Data 2 [00:53:00 - 00:53:19]

Gabriel: I'll find you when it's over.

Benjamin: No! I forbid you to go!

Gabriel: I'm not a child!

Benjamin: You are my child!

Gabriel: Good bye, Father.

Benjamin: Thomas is dead. How many more have to die before you'll hear my word? I'm losing my family.

(Source:

http://www.veryabc.cn/movie /uploads/script/ThePatriot.txt)

Analysis:

Thomas is shot dead by British Colonel after he tries to save Gabriel from hang punishment. Benjamin is indignant seeing the fact that his beloved children already die and his house was burned. As a result, Benjamin and his sons try to save Gabriel by killing British troop in guerrilla way. After the situation is safe, Benjamin and his family including Gabriel live temporarily in Charlotte's house. However, the next day, Gabriel decides to come back to the war because he feels that his duty is to serve his country, but, Benjamin is still on his decision which is not allowing his son to go.

The statement stated by Benjamin in the part of the dialogue above which is 'you are my child!' applies the informal style of politeness level, in addition, it is indicating that Benjamin as a man try to interrupt and dominate the hearer, in this case, Gabriel. This utterance is also shows Benjamin's power, he has a power to forbid or allow Gabriel to go. In this case, Benjamin as a man is talk more about facts rather than his feeling. It can be seen from his last statement 'Thomas is dead. How many more have to die before you'll hear my word?'

\section{CONCLUSION}

The character in The Patriot movie applied eleven strategies proposed by Brown and Levinson, namely Notice, attend to $\mathrm{H}$ (his interests, wants, needs, goods), Intensify interest to $\mathrm{H}$, Use ingroup identity markers, Seek agreement, Avoid disagreement, Joke, Assert or presuppose S's knowledge of and concerns for H's wants, Offer, promise, Include both $\mathrm{S}$ and $\mathrm{H}$ in the activity, Give (or ask for) reasons, and the last one is Give gifts to $\mathrm{H}$ (goods, sympathy, understanding, cooperation).

Regarding to the gender of the character, in this case, women consistently tend to use neutral style when they have a conversation both with woman or man. It is due to woman psychologically tend to be involved with one another and to be mutually supportive and non-competitive. On the 
other hand, men is using various level of formality when they having a conversation, such as formal style, informal style, and neutral style. It is due to men is tend to take control the conversation and try to dominate the hearer when they are talking.

\section{REFERENCES}

Brown, Penelope; and Levinson, Stephen. (1987). Politeness, some universal in language usage. Cambridge: Cambridge University Press.

Coates, Jennifer. (2004). Women, Men and Language: A Sociolinguistic Account of Gender Differences in Language. Routledge.

Holmes, Jannet. (1992). An Introduction to Sociolinguistics: Language in Society (serial online). London: Longman, (cited 2009 Feb. 01). Available fromURL: https://www.cambridge.org/

Lakoff, Robin. (1973). Langauge and Women's Place. Language in Society. Cambridge: Cambridge University Press.

Lakoff, Robin. (1975). Language and Woman's Place. Language in Society (Vol. 2). Cambridge University Press, Cambridge.

Wardhaugh, Ronald; and Fuller, Jannet . (2010). An Introduction To Sociolinguistics, Seventh Edition. Wiley Blackwell, West Sussex.

Wardhaugh, Ronald (2010). An Introduction To Sociolinguistics, Sixth Edition. Wiley Blackwell, West Sussex.
Xia, Xiufang (2013). Gender Differences in Using Language. Theory and Practice in Language Studies, Vol. 3, No. 8, pp. 1485-1489.

Nemati, A., \& Bayer, J. M. (2007). Gender Differences in the Use of Linguistic Forms in the Speech of Men and Women: A Comparative Study of Persian and English. International Journal of Applied Linguistic, Vol. 2, pp. 185-201.

Ogawa, Naoto and Gudykunst, William B (2000). Politeness Rules in Japan and the United States. Intercultural Communication Studies, Vol. IX, pp. 47-69

Pariera, Katrina. (2006). The Use of Politeness Strategies in Email Discussions about Taboo Topics. PSU McNair Scholars Online Journal. Vol. 2, pp. 320-341

Sando, Yves Talla. O. (2006). Politeness Strategies in Colloquaial Cameroon English: Focus on Three Pragmatic Particles: na, ya, and eihn. Nordic Journal of African Studies. Vol. 15. Issue: 4 Pages: 536-544.

Bacha, Nala Nohla. (2012). Gender and Politeness in a Foreign Language Academic Context. International Journal of English Linguistic. Vol. 2, No. 1; February 2012, pp 79-82

Khorshidi, Hassan Rasouli. (2013). Politeness in Study Abroad. International Research Journal of Applied and Basic Sciences. Vol, 5 (3), pp 324-333

http://www.veryabc.cn/movie/uploads/sc ript/ThePatriot.txt 